\title{
PENGEMBANGAN MODEL PEMBELAJARAN KOMPREHENSIF DALAM PENDIDIKAN ILMU PENGETAHUAN SOSIAL DI SEKOLAH DASAR
}

\author{
Usep Supriatna \\ FKIP Universitas PGRI Ronggolawe Tuban \\ Email: usep.supriatna14@gmail.com
}

\begin{abstract}
ABSTRAK
Pembelajaran secara komprehensif merupakan langkah implementasi dari rencana pembelajaran terpadu secara menyeluruh, berisi rincian dari prosedur pembelajaran. Penelitian ini bertujuan untuk mengembangkan model pembelajaran komprehensif dalam Pendidikan IPS di Sekolah Dasar, yang difokuskan untuk meningkatkan keterampilan sosial siswa. Jenis penelitian ini adalah pengembangan (Research and Development) yang disederhanakan atas tahapan studi pendahuluan, pengembangan dan uji validasi. Penelitian dilakukan pada kelas lima Sekolah Dasar, mengambil lokasi di Kota Tuban Jawa Timur. Model pembelajaran yang dihasilkan adalah Pembelajaran Komprehensif dalam Pendidikan IPS sebagai pengembangan dari perpaduan STAD, TGT, JIGSAW. Ada empat langkah utama yang merupakan sintaks dari model pembelajaran komprehensif dan terpadu hasil pengembangan, yaitu langkah: orientasi, eksplorasi, pemantapan dan penyimpulan. Langkah Orientasi atau kegiatan awal pembelajaran merupakan langkah untuk mendorong kelas memusatkan perhatian terhadap pembelajaran; Langkah Eksplorasi atau kegiatan inti pertama, merupakan langkah untuk mengajak dan mendorong siswa untuk mencari dan menemukan fakta, pengetahuan, masalah dan pemecahan; Langkah Pemantapan atau kegiatan inti kedua, merupakan langkah untuk memperdalam, memperluas, memantapkan, memperkuat penguasaan materi dan kemampuan yang telah dicapai pada langkah eksplorasi; dan. Langkah Penyimpulan atau kegiatan akhir pembelajaran, merupakan langkah untuk menyimpulkan atau merangkumkan dan menegaskan tentang apa yang telah dipelajari.
\end{abstract}

Kata Kunci: Pengembangan model Pembelajaran komprehensif, keterampilan sosial

\begin{abstract}
Learning is a comprehensive step in the implementation of the integrated learning plan as a whole, containing details of the learning procedure. This study is purposed to develop a comprehensive model of learning in social science stream in elementary schools, focused on improving the social skills of students. The research is using the development (Research and Development), a simplification on the stage of preliminary studies, development and test validation. The study was conducted on a fifth-grade elementary school, taking place in the city of Tuban, East Java. The resulting model of learning is comprehensive learning on Social Science education as the development of enhanced STAD, TGT, JIGSAW models. There are four main steps that constitute the syntax from the comprehensive and integrated learning model development results, namely: orientation, exploration, consolidation and inference. Orientation step, or the early learning activities, is the step to encourage the class to be focused on learning; Exploration step, or the first core activities, is a step to invite and encourage students to seek and find the facts, knowledge, and the problem solving; Step Consolidation step, or second core activity, is a step to deepen, broaden, and strengthen the mastery of the material and the ability that has been achieved on the exploration step; Inference step,
\end{abstract}


or the end of the learning activity, is a step to conclude or summarize and confirms what has been learned.

Keywords: Development of a comprehensive model of learning social skills

\section{PENDAHULUAN}

Bangsa Indonesia dihadapkan pada permasalahan multi dimensi yang menyentuh berbagai tatanan kehidupan mendasar manusia. Bukan hanya berkaitan dengan aspek ekonomi, namun juga aspek sosial, budaya dan ahlak. Krisis pada aspek sosial khususnya sudah sampai pada bentuk yang cukup memprihatinkan. Penyimpangan perilaku sosial tidak hanya diperlihatkan oleh para siswa tetapi juga para mahasiswa, bahkan orang dewasa dalam bentuk perilaku-perilaku kekerasan, pemaksaan kehendak, pengrusakan, konflik antar kelompok serta tawuran. Berbagai bentuk kemiskinan sosial juga banyak diperlihatkan, seperti miskin pengabdian, kurang disiplin, kurang empati terhadap masalah sosial, kurang efektif berkomunikasi serta kurang disiplin. Hal itu menunjukkan adanya permasalahan pribadi dan sosial di kalangan masyarakat berpendidikan tinggi.

Pada kalangan siswa sekolah dasar dan menengah, seperti juga masyarakat pada umumnya gejala masalah pribadi dan sosial ini juga tampak dalam perilaku keseharian. Sikap-sikap individualistis, egoistis, acuh tak acuh, kurangnya rasa tanggung jawab, malas berkomunikasi dan berinteraksi atau rendahnya empati merupakan fenomena yang menunjukkan adanya kehampaan nilai sosial dalam kehidupan sehari-hari. Sesungguhnya dalam menghadapi kondisi yang demikian, pendidikan dapat memberikan kontribusi yang cukup besar. Pendidikan dapat memberikan kontribuasi dalam mengatasi masalah sosial sebab pendidikan memiliki fungsi dan peran dalam meningkatkan sumber daya manusia. Sumber daya manusia dapat menjadi kekuatan utama dalam mengatasi dan memecahkan masalah sosial-ekonomi yang dihadapi, namun demikian. sumber daya manusia juga dapat menjadi faktor penyebab munculnya masalahmasalah tersebut. Naisbitt (dalam Fong 1999) menegaskan bahwa " Education and traning must be a major priority, they are the keys to maintaining competitiveness". Sumber daya manusia yang berkualitas, dengan pegangan norma dan nilai yang kuat, kinerja dan disiplin tinggi yang dihasilkan oleh pendidikan yang berkualitas dapat menjadi kekuatan utama untuk mengatasi masalah-masalah yang dihadapi. Sebaliknya sumber daya manusia yang tidak berkualitas, lemah dalam pegangan norma dan nilai, rendah disiplin dan kinerja yang dihasilkan oleh pendidikan yang kurang berkualitas dapat merupakan pangkal dari permasalahan yang dihadapi.

Meskipun begitu strategis kedudukan pendidikan untuk perubahan suatu bangsa namun bangsa kita belum cukup optimis untuk mengandalkan posisi tersebut karena pada kenyatannnya kondisi dan hasil pendidikan kita belum memadai. Kondisi tersebut nampak dari kecilnya kemampuan sumber daya manusia Indonesia untuk berkompetisi dengan bangsa lain. Data yang dipublikasikan oleh United Development Index (HDI) sangat memprihatinkan karena dari tahun 1996 dimana posisi Indonesia berada pada peringkat 102 terus menurun hingga pada tahun 2000 berada pada peringkat 
109, berada satu tingkat di atas Vietnam, padahal Negara-negara ASEAN lain berada pada peringkat jauh di atas Indonesia.

Persoalan pendidikan di Indonesia selayaknya mendapat perhatian semua pihak secara lebih profesional dan akurat serta penelaahan dan kajian-kajian secara lebih mendalam. Namun cara tersebut sangat sulit dilakukan sehingga perlu ada prioritas. Tanpa mengurangi arti dan pentingnya jalur dan jenis pendidikan lain, pendidikan dasar, khususnya pada tingkat sekolah dasar memiliki posisi sangat strategis karena menjadi landasan bagi pendidikan selanjutnya. Pendidikan dasar yang bermutu akan memberikan landasan yang kuat bagi pendidikan menengah dan pendidikan tinggi yang bermutu pula. Sekolah Dasar juga memiliki populasi terbesar (sekitar 30 juta orang) dibandingkan dengan siswa SLTP dan SLTA. Secara khusus, peranan pendidikan dasar bagi pengembangan anak dan remaja dirumuskan sebagaimana tercantum dalam Peraturan Menteri Pendidikan Nasional nomor 23 tahun 2006, bahwa pendidikan dasar bertujuan: meletakkan dasar kecerdasan, pengetahuan, kepribadian, akhlak mulia serta keterampilan untuk hidup mandiri dan mengikuti pendidikan lebih lanjut. Tujuan tersebut dicapai melalui proses pembelajaran dalam kelompok mata pelajaran: (1) Agama dan akhlak mulia,

(2) Kewarganegaraan dan Kepribadian,

(3) Ilmu Pengetahuan dan Teknologi, (4) Estetika, (5) Jasmani, Olah Raga dan Kesehatan.

Baik tujuan pendidikan maupun kelompok mata pelajaran pada pendidikan dasar, pada dasarnya diarahkan pada pengembangan pribadi siswa, kemampuan hidup bermasyarakat dan kemampuan untuk melanjutkan studi. Ketiga aspek pengembangan tersebut saling terkait dapat dibedakan tetapi sulit untuk dipisahkan. Semua mata pelajaran yang diberikan pada Sekolah Dasar memberikan sumbangan terhadap pengembangan ketiga aspek tersebut, tetapi bobotnya tidak sama. Secara umum pengembangan pribadi lebih banyak berkenaan dengan penguasaan segi agama dan akhlak mulia, kepribadian, estetika, jasmani, olah raga dan kesehatan. Kemampuan kemasyarakatan banyak berkenaan dengan kewarganegaraan dan kepribadian, sedang kemampuan melanjutkan studi banyak berkenaan dengan penguasaan pengetahuan dan teknologi.

Semua mata pelajaran walaupun bobotnya berbeda-beda dapat berperan dalam mengatasi atau mengurangi masalah dan perilaku penyimpangan sosial dan pribadi tetapi mata pelajaran Ilmu pengetahuan Sosial dan Pendidikan Kewarganegaraan memegang peran yang lebih besar. Kemampuan pribadi dan sosial berkenaan dengan penguasaan karakteristik, nilai-nilai sebagai pribadi dan sebagai warga masyarakat serta kemampuan untuk hidup bermasyarakat. Penguasaan karakteristik dan nilainilai pribadi dan warga masyarakat banyak dikembangkan dalam Pendidikan Kewarganegaraan, sedang kemampuan untuk hidup bermasyarakat banyak dikembangkan dalam pelajaran Ilmu Pengetahuan Sosial.

Ilmu Pengetahuan Sosial (IPS) pada jenjang pendidikan dasar memfokuskan kajiannya kepada hubungan antar manusia dan proses membantu pengembangan kemampuan dalam hubungan tersebut. Pengetahuan, keterampilan dan sikap yang dikembangkan melalui kajian ini ditujukan untuk mencapai keserasian dan 
keselarasan dalam kehidupan masyarakat. Pendidikan IPS sudah lama dikembangkan dan dilaksanakan dalam kurikulumkurikulum di Indonesia, khususnya pada jenjang pendidikan dasar. Pendidikan ini tidak dapat disangkal telah membawa beberapa hasil, walaupun belum optimal. Secara umum penguasaan pengetahuan sosial atau kewarga-negaraan lulusan pendidikan dasar relatif cukup, tetapi penguasaan nilai dalam arti penerapan nilai, keterampilan sosial dan partisipasi social hasilnya belum menggembirakan. Kelemahan tersebut sudah tentu terkait atau dilatarbelakangi oleh banyak hal, terutama proses pendidikan atau pembelajarannya, kurikulum, para pengelola dan pelaksanaanya serta faktorfaktor yang berpengaruh lainnya.

Beberapa temuan penelitian dan pengamatan ahli memperkuat kesimpulan tersebut. Dalam segi hasil atau dampak pendidikan Ilmu Pengetahuan Sosial atau IPS terhadap kehidupan bermasyarakat, masih belum begitu nampak. Perwujudan nilai-nilai sosial yang dikembangkan di sekolah belum nampak dalam kehidupan sehari-hari, keterampilan sosial para lulusan pendidikan dasar khususnya masih memprihatinkan, partisipasi dalam berbagai kegiatan kemasyarakatan semakin menyusut.

Banyak penyebab yang melatarbelakangi mengapa pendidikan IPS belum dapat memberikan hasil seperti yang diharapkan. Faktor penyebabnya dapat berpangkal pada kurikulum, rancangan, pelaksanaan ataupun faktor pendukung pembelajaran. Berkenaan dengan kurikulum dan rancangan pembelajaran IPS, beberapa penelitian sebelumnya memberi gambaran tentang kondisi tersebut. Hasil penelitian Balitbang Depdikbud tahun 1999 menyebutkan bahwa " Kurikulum 1994 tidak disusun berdasarkan basic competencies melainkan pada materi, sehingga dalam kurikulumnya banyak memuat konsepkonsep teoretis (Boediono, et al. 1999: 84). Hasil Evaluasi Kurikulum IPS SD Tahun 1994 menggambarkan adanya kesenjangan kesiapan siswa dengan bobot materi sehingga materi yang disajikan dianggap terlalu sulit bagi siswa, kesenjangan antara tuntutan materi dengan fasilitas pembelajaran dan buku sumber, kesulitan manajemen waktu, serta keterbatasan kemampuan melakukan pembaharuan metode mangajar (Depdikbud, 1999).

Implementasi materi IPS lebih menekankan aspek pengetahuan, berpusat pada guru, mengarahkan bahan berupa informasi yang tidak mengembangkan berpikir nilai serta hanya membentuk budaya menghafal dan bukan berpikir kritis. Dalam pelaksanaan Nu'man S. (2001) menilai pembelajaran IPS sangat menjemukan karena penyajiannya bersifat monoton dan ekspositoris sehingga siswa kurang antusias dan mengakibatkan pelajaran kurang menarik pada hal menurut Nursid S (1986: 35) guru IPS wajib berusaha secara optimum merebut minat siswa karena minat merupakan modal utama untuk keberhasilan pembelajaran IPS. Selanjutnya Como dan Snow (dalam Syafruddin, 2001:3) menilai bahwa model pembelajaran IPS yang diimplementasikan saat ini masih bersifat konvensional sehingga siswa sulit memperoleh pelayanan secara optimal. Dengan pembelajaran seperti itu maka perbedaan individual siswa di kelas tidak dapat terakomodasi sehingga sulit tercapai tujuan-tujuan spesifik pembelajaran terutama bagi siswa berkemampuan rendah. Model pembelajaran IPS saat ini juga 
lebih menekankan pada aspek kebutuhan formal dibanding kebutuhan riil siswa sehingga proses pembelajaran terkesan sebagai pekerjaan administratif dan belum mengembangkan potensi anak secara optimal.

Berdasarkan hal-hal di atas nampak bahwa pada satu sisi betapa pentingnya peranan pendidikan IPS dalam mengembangkan pengetahuan, nilai, sikap, dan keterampilan sosial agar para siswa menjadi warga masyarakat, bangsa dan Negara Indonesia yang baik namun di pihak lain masih banyak ditemukan kelemahan dalam pembelajaran IPS, baik dalam rancangan maupun proses pembelajaran. Untuk mengatasi masalahmasalah tersebut diperlukan penelitian berkaitan dengan pembelajaran IPS. Salah satu upaya yang memadai untuk itu adalah dengan melakukan pengembangan model pembelajaran yang mampu meningkatkan keterampilan sosial, sebagai sasaran utamanya, disamping itu juga meningkatkan pengetahuan serta pengembangan sikap sebagai sasaran

\section{Batasan dan Rumusan Masalah}

Penelitian ini diarahkan pada pengembangan model pembelajaran secara komprehensif terhadap pendidikan IPS di sekolah dasar. Pada jenjang tersebut kajian IPS bersifat umum, terpadu dan komprehensif, belum disajikan dalam bentuk teoritis-konseptual. Kalaupun disajikan baru dasar-dasarnya saja dengan pengorganisasian materi menggunakan model " broadfield" atau bidang studi dimana ada terkandung aspek-aspek sejarah, geografi, ekonomi atau budaya dan politik tetapi terintegrasi dalam tematema.

Keberhasilan pembelajaran IPS dipengaruhi banyak faktor, yaitu input, proses dan output sebagai suatu sistem. Komponen input mencakup raw input (masukan mentah), instrumental input (masukan instrumental) dan environmental input (masukan lingkungan). Komponen proses berkenaan dengan pembelajaran teori, pembelajaran praktek, pengelolaan kelas, pemberian tugas dan latihan, bimbingan siswa, evaluasi serta manajemen pembelajaran sedangkan komponen output berkenaan dengan perubahan positif atau perkembangan yang dicapai setelah melakukan proses pembelajaran secara komprehensif. Dengan begitu banyaknya variabel yang melatar belakangi dan mempengaruhi keberhasilan pembelajaran maka untuk bahan dasar pengembangan model akan digunakan beberapa variabel yang secara konseptual paling dominan memberikan kontribusi data dalam pengembangan model, khususnya pada studi pendahuluan.

Variabel-variabel yang secara khusus akan diteliti tersebut adalah komponen guru, siswa, konteks atau lingkungan serta proses pembelajarannya. Pada komponen guru,variabel yang akan diteliti dibatasi pada latar belakang pendidikan dan latihan yang pernah diikuti, pengetahuan, keterampilan dan motivasi dalam pembelajaran IPS. Dalam komponen siswa akan dibatasi pada motivasi belajar, pengetahuan dan keterampilan dalam bidang sosial saat ini. Komponen konteks atau lingkungan dibatasi pada sarana dan prasarana pembelajaran, media dan sumber belajar yang ada. Pada komponen proses pembelajaran dibatasi pada model atau metode pembelajaran yang digunakan dan implementasinya. Pendidikan IPS di sekolah dasar diarahkan pada penguasaan pengetahuan, nilai, sikap dan keterampilan siswa sebagai warga negara Indonesia. 
Dengan sasaran yang sangat luas tersebut, mengacu pada latar belakang masalah sebagaimana diuraikan di atas maka penelitian ini akan dibatasi pada penguasaan keterampilan sosial. Penelitian dibatasi pada satu tingkat saja, yaitu kelas Sekolah Dasar, dengan pertimbangan bahwa dari sisi perkembangan kemampuan sosial, siswa sudah mampu menjalin hubungan dengan teman sebaya karena pada usia tersebut ikatan sebaya sangat kuat. Pada tingkatan tersebut siswa juga sudah mendapatkan pelajaran IPS minimal dua tahun sehingga dipandang cukup memiliki dasar umum pengetahuan, sikap, nilai dan keterampilan sosial.

Berdasarkan latar belakang dan pemikiran sebagaimana diuraikan di atas, penelitian ini difokuskan pada pengembangan model pembelajaran komprehensif dalam Pendidikan IPS di Sekolah Dasar kelas 5 SDN Latsari 1 di Kabupaten Tuban, diharapkan dapatmemberi kontribusi memadai untuk meningkatkan keterampilan sosial siswa. Secara khusus diarahkan untuk a) menemukan model dan model desain yang memadai, b) model implementasi, serta c) Faktor pendukung, kelebihan dan hambatan dalam implementasi model pembelajaran tersebut.

\section{METODE}

Penelitian ini difokuskan pada pengembangan model pembelajaran komprehensif dalam bidang IPS yang diarahkan pada peningkatan keterampilan sosial siswa Sekolah Dasar. Pengembangan suatu model pembelajaran terkait dengan segi dan aspek yang akan dikembangkan; pada mata pelajaran apa, segi atau aspek tersebut akan dikembangkan pada siapa, jenjang dan jenis pendidikan mana serta bagaimana kondisinya.
Untuk mengakomodasi pertanyaan tersebut dengan karakteristik sebagaimana digambarkan di atas maka digunakan metode penelitian dan pengembangan atau Research and Development yang disederhanakan atas tahapan studi pendahuluan, pengembangan dan uji validasi. Penelitian dilakukan pada kelas lima Sekolah Dasar, mengambil lokasi di Kota Tuban Jawa Timur. Penentuan sampel pada studi pendahuluan menggunakan teknik stratafied cluster random sampling berdasarkan lokasi kecamatan dan sekolah sehingga diperoleh 25 sekolah dengan variasi katagori kluster.

Pengembangan model pembelajaran dilakukan pada dua sekolah (satu SD negeri dan satu SD swasta) untuk uji coba terbatas dan tiga sekolah (dua SD negeri dan satu SD swasta) untuk uji coba luas sedangkan untuk uji validasi dilaksanakan pada enam sekolah, yaitu tiga SD sebagai kelompok eksperimen dan tiga SD lain untuk kelompok sosial dengan variasi katagori baik, cukup dan sedang. Pelaksanaan penelitian dilakukan atas tiga tahap, yaitu studi pendahuluan yang meliputi studi kepustakaan dan survai, pengembangan model yang meliputi uji coba terbatas dan uji coba luas serta pengujian hasil yang dilaksanakan melalui eksperimen. Pada tahap studi pendahuluan data dikumpulkan menggunakan metode survai dengan tehnik observasi, angket dan wawancara serta studi dokumenter. Tahap pengembangan nmenggunakan metode penelitian tindakan yang dikembangkan atas kegiatan penyusunan rencana, pelaksanaan, evaluasi dan penyempurnaan pembelajaran. Pada tahap ini juga dilakukan evaluasi terhadap proses dengan cara observasi dan evaluasi hasil berbentuk tes. Selanjutnya, pada tahap 
pengujian, dengan menggunakan metode eksperimen pengumpulan data dilakukan dengan tehnik observasi berbentuk sekala untuk menilai peningkatan keterampilan sosial siswa dan tes tertulis berbentuk pilihan ganda untuk menilai hasil belajar dalam penguasaan materi (pengetahuan) IPS.

Analisis data yang digunakan pada tahapan studi pendahuluan adalah analisis deskriptif kuantitatif dan kualitatif.Analisis kuantitatif digunakan untuk menganalisis data angket utnuk dicari frekuensi dari setiap jawabannya sehingga diperoleh gambaran kecenderungan umum kondisi dan potensi di lapangan. Data kualitatif dari hasil wawancara, observasi dan studi sosial digunakan sebagai pelengkap data sehingga diperoleh gambaran objektif dan menyeluruh tentang kondisi dan implementasi pembelajaran IPS di sekolah.

Data hasil observasi pada tahap pengembangan model dianalisis secara kualitatif. Hasilnya dikomunikasikan dengan para guru untuk penyempurnaan rancangan dan pelaksanaan pembelajaran selanjutnya. Data hasil berupa nilai tes IPS pada uji coba terbatas dan luas dianalisis dengan uji t dengan menggunakan program SPSS versi 12 . Perolehan data kualitatif dalam bentuk skor nilai tes awal dan tes akhir keterampilan sosial pada uji validasi diolah menggunakan uji t dengan SPSS versi 12 sehingga terlihat perbedaan hasil antara keduanya pada masing-masing kelompok.

\section{HASIL DAN PEMBAHASAN}

\section{Model Pembelajaran Komprehensif yang Dihasilkan}

Model pembelajaran yang dihasilkan adalah Pembelajaran Komprehensif sebagai pengembangan dari perpaduan
Student Teams-Achievement Divisions (STAD) atau Pembelajaran Peningkatan Prestasi Tim (PPPT); Teams-Games Tournament (TGT) atau Pembelajaran Permainan Tim (PPT); Jigsaw atau Permainan Keahlian Tim (PKT) dari Slavin dan Pembelajaran Komprehensif dari A.Lie. Perbandingan langkah-langkah pembelajaran dari masing-masing model diilustrasikan sebagai berikut:

\section{Model Desain Pembelajaran Komprehensif}

Model desain pembelajaran menyajikan rencana pembelajaran dan prosedur pembelajaran komprehensif

\section{a. Rencana pembelajaran}

Rencana pembelajaran komprehensif berisi komponen-komponen yang sama dengan rencana pembelajaran sebagaimana digunakan di sekolah, yang biasa disebut rencana pelaksanaan pembelajaran (RPP), tetapi memiliki spesifikasi untuk mengajarkan tema atau topik-topik IPS yang menekankan keterampilan sosial. Enam komponen dari rencana pembelajaran tersebut adalah:

1) Tema/topik, berisi nama tema/topik yang akan diajarkan. Tema/ topik tersebut diambil dari kurikulum (silabus) IPS pada semester yang sesuai bagi pembelajaran keterampilan sosial, bermakna dan dekat dengan kehidupan / keseharian siswa.

2) Tujuan Pembelajaran, merupakan sasaran yang akan dicapai dalam pembelajaran. Tujuan tersebut berisi rumusan kompetensi yang diharapkan dikuasai oleh para siswa. Tujuan pembelajaran terbagi dua, yaitu tujuan pembelajaran umum dan tujuan pembelajaran khusus. Tujuan pembelajaran umum, berisi rumusan kompetensi dasar berkenaan dengan topik yang akan diajarkan, sedang tujuan pembelajaran khusus, berisi 
rumusan-rumusan indikator dari topik yang akan diajarkan.

3) Materi Pembelajaran, merupakan isi atau substansi bahan yang akan diajarkan, yang menunjang penguasaan kompetensi yang menjadi tujuan pembelajaran. Materi pembelajaran ini hanya memuat garis-garis besar bahan ajaran yang merupakan rincian dari topik pembelajaran.

4) Model Pembelajaran, berisi rumusan tentang model pembelajaran komprehensif dengan variasi metode yang akan digunakan. Jenis metode yang digunakan dalam setiap pertemuan tidak selalu sama, disesuaikan dengan topik dan kompetensi yang akan dicapai. Metode-metode tersebut pada umumnya merupakan metode yang berisi kegiatan yang mengaktifkan siswa (seperti bekerja dan diskusi kelompok, presentasi, menanggapi, mengemukakan pendapat, memimpin), dalam berbagai kegiatan kelompok, bersifat inkuiri atau diskaveri yang ber- makna. Meskipun demikan tidak berarti tidak boleh menggunakan metode yang bersifat ekpositori dan klasikal, kalau diperlukan sesuai topik dan kompetensi yang akan dicapai metode-metode tersebut juga dapat digunakan.

5) Media dan Sumber Pembelajaran, berisi rumusan tentang media atau alat bantu pembelajaran yang digunakan untuk membantu memperjelas atau mempermudah penguasaan materi atau kompetensi yang ingin dicapai. Media pembelajaran dapat menggunakan media yang sudah ada di sekolah atau diadakan oleh guru dan siswa. Sumber pembelajaran dapat berupa buku, majalah dan bahan cetak lain, bahan elektronik, orang atau nara sumber, dan sumber pembelajaran yang ada di lingkungan masyarakat.

6) Evaluasi Pembelajaran, merupakan kegiatan untuk mengukur dan menilai pencapaian tujuan yang telah dirumuskan. Evaluasi ini meliputi evaluasi proses dan evaluasi hasil pebelajaran. Evaluasi proses ditujukan untuk menilai perilaku atau keterampilan sosial siswa dalam berbagai kegiatan pembelajaran, seperti bekerja dan diskusi dalam kelompok kecil, kelompok sedang, kelompok besar dan dalam kelas. Evaluasi hasil ditujukan untuk mengukur dan menilai tingkat penguasan siswa dalam kompetensi dan materi yang dirumuskan dalam tujuan. Pengukuran menggunakan kuis, tes obyektif dan uraian.

\section{b. Prosedur Pembelajaran.}

Prosedur pembelajaran berisi langkah-langkah umum dan rincian singkat dari metode atau kegiatan model pembelajaran komprehensif. Prosedur ini dibuat untuk membantu mempermudah guru dalam menguasai dan melaksanakan langkah-langkah pembelajaran menyeluruh dan komprehensif. Dalam prosedur ini ada empat langkah utama, yaitu langkah: orientasi, eksplorasi, pendalaman dan penyimpulan. Langkah orientasi berisi kegiatan: pengenalan, dan pengkondisian; langkah eksplorasi berisi kegiatan: menyimak penjelasan, membaca bahan, bekerja atau berdiskusi kelompok, dan bekerja atau diskusi antar kelompok; langkah pemantapan berisi kegiatan: bekerja kelompok secara kelas, beriskusi kelas dan tes tertulis ; langkah penyimpulan berisi kegiatan: pembuatan kesimpulan dan pemberian tugas. 


\section{Implementasi Model Pembelajaran.}

Pelaksanaan pembelajaran merupakan langkah implementasi dari rencana pembelajaran komprehensif, berisi rincian dari prosedur pembelajaran. Sama dengan pada prosedur ada empat langkah utama yang merupakan sintaks dari model pembelajaran komprehensif hasil pengembangan, yaitu langkah: orientasi, eksplorasi, pendalaman dan penyimpulan.

a. Langkah Orientasi atau kegiatan awal pembelajaran merupakan langkah untuk mendorong kelas memusatkan perhatian terhadap pembelajaran. Langkah ini berisi kegiatan:

1) Curah pendapat, apersepsi atau menghubungkan materi baru dengan yang sudah dikuasai.

2) Pengkondisian kelas berisi penciptaan situasi, pemberian motivasi dan penjelasan tentang langkah-langkah pembelajaran yang akan dilakukan.

b. Langkah Eksplorasi atau kegiatan inti pertama, merupakan langkah untuk mengajak dan mendorong siswa untuk mencari dan menemukan fakta, pengetahuan, masalah dan pemecahan. Dalam proses pencarian tersebut siswa berlatih mengembangkan keterampilan berinteraksi, berpartisipasi, berkomunikasi.

Kegiatan-kegiatan utama yang dilakukan dalam langkah eksplorasi adalah:

1) Siswa menyimak penjelasan dari guru tentang bahan yang akan dipelajari

2) Secara individual dan kelompok siswa membaca tentang topik yang akan dipelajari.

3) Bekerja kelompok: mengerjakan tugas, latihan, menjawab soal yang diberikan, menyiapkan bahan untuk penyajian.
4) Diskusi kelompok: mengemukakan pengetahuan atau pendapat, mengajukan tanggapan, mempertahankan pendapat, memberikan penilaian.

5) Bekerja antar kelompok: memadukan hasil pekerjaan kelompok,

6) Diskusi antara kelompok: penyajian hasil kerja kelompok, kompetisi dalam menganggapi, memberikan jawaban, siswa/guru memberikan penilaian, mengadakan penyempurnaan.

c. Langkah pemantapan atau kegiatan inti kedua, merupakan langkah untuk memperdalam, memperluas, memantapkan, memperkuat penguasaan materi dan kemampuan yang telah dicapai pada langkah eksplorasi. Kegiatan-kegiatan utama yang dilakukan pada langkah ini meliputi:

1) Kerja kelompok kelas: memadukan hasil kerja antar kelompok, mengadakan penyempurnaan, menyiapkan bahan penyajian.

2) Diskusi kelas: bergiliran atau berkompetisi sosial penjelasan dan tanggapan, guru dan/atau siswa memberi penilaian.

3) Melalui tanya-jawab guru mengajak siswa memadukan hasil kerja dan diskusi kelas.

4) Evaluasi dalam bentuk tes tertulis bentuk obyektif atau uraian.

d. Langkah Penyimpulan atau kegiatan akhir pembelajaran, merupakan langkah untuk menyimpulkan atau merangkumkan dan menegaskan tentang apa yang telah dipelajari. Langkah penyimpulan berisi kegiatan:

1) Guru menyimpulkan materi dan kemampuan yang telah dipelajari dan dilatihkan.

2) Guru menegaskan pentingnya materi dan kemampuan yang telah dipelajari dalam pendidikan dan kehidupan yang akan datang. 
4. Faktor Pendukung Model Pembelajaran Komprehensif

Efektifitas pembuatan rancangan dan implementasi model pembelajaran ini sangat didukung oleh berbagai faktor sebagai berikut:

a. Guru, berkenaan dengan kemapanan guru dalam berbagai aspek, di antaranya kualifikasi pendidikan, potensi dan kondisi, persepsi terhadap profesi dan tugas mengajar serta kemampuan dan kecakapan menyelenggarakan serta mengelola pembelajaran yang sesuai dengan karakteristik model pembelajaran.

b. Siswa, berkenaan dengan karakteristik, potensi, minat, kemampuan dan persepsinya terhadap pembelajaran kooperatif serta pelajaran IPS.

c. Sarana-prasarana, sumber belajar, media dan alat bantu belajar, berkenaan dengan ketersediaan, keberfungsian dan kreatifitas penyajian dan pemanfaatanya oleh guru.

d. Ukuran, kondisi dan suasana kelas. Ukuran berkaitan dengan luas dan pemanfaatan ukuran kelas; kondisi kelas berkenaan dengan penataan sarana dan prasarana di kelas sehingga kondusif untuk pembelajaran kooperatif sedangkan suasana kelas berkenaan dengan iklim belajar dan kegiatan kerjasama dalam pembelajaran.

e. Waktu. Efektivitas implementasi model pembelajaran kooperatif membutuhkan waktu yang memadai dengan pemanfaatan yang optimal dan bermakna.

5. Kelebihan Model Pembelajaran Komprehensif yang Dihasilkan

Model pembelajaran komprehensif hasil pengembangan memiliki kelebihan dibandingkan dengan model pembelajaran biasa dalam dua aspek yang menjadi sasaran pembelajaran, yaitu penguasaan: keterampilan sosial dan pengetahuan.

Kelebihan dari model pembelajaran komprehensif ini diperlihatkan oleh perbedaan tingkat penguasan yang cukup berarti dari hasil tes akhir dibandingkan dengan hasil tes awal, baik dalam aspek keterampilan sosial maupun pengetahuan IPS. Temuan tersebut diperkuat oleh hasil analisis perbedaan antara kelompok eksperimen dengan kelompok kontrol. Kelompok eksperimen atau yang menggunakan model pembelajaran kooperatif memiliki tingkat penguasaan dalam aspek keterampilan sosial dan pengetahuan yang lebih tinggi dan perbedaannya cukup berarti dibandingkan dengan kelompok kontrol. Dalam tes awal pasangan-pasangan tersebut tidak menunjukkan perbedaan yang berarti, atau perbedaannya berarti tetapi jauh lebih kecil dibandingkan dengan pada tes akhir.

\section{a. Penguasaan keterampilan sosial}

1) Setelah belajar dengan menggunakan model pembel-ajaran komprehensif, penguasaan keterampilan sosial lebih tinggi. Skor rata-rata (mean) hasil tes akhir lebih besar dan berbeda secara signifikan dibandingkan dengan hasil tes awal.

2) Perbedaan tersebut diperkuat oleh hasil uji perbedaan dengan kelompok kontrol. Dalam setiap pasangan sekolah eksperimen dengan sekolah sosial diperoleh hasil bahwa skor rata-rata keterampilan sosial dari sekolah-sekolah kelompok eksperimen lebih tinggi dari rata-rata skor sekolah kelompok kontrol, dengan perbedaannya sangat berarti.

2) Model pembelajaran komprehensif memberikan hasil lebih baik dalam pengembangan keterampilan sosial, di 
antaranya karena menggunakan berbagai variasi kegiatan pembelajaran kelompok sehingga banyak memberikan kesempatan untuk berlatih keterampilan sosial. Hal itu berarti bahwa model pembelajaran kooperatif cocok digunakan untuk pengembangkan keterampilan sosial.

3) Adanya kecenderungan bahwa implementasi model pembelajaran komprehensif memberikan dampak yang berragam (variatif) terhadap keterampilan sosial siswa, terutama pada siswa dari sekolah kategori menengah. Dengan demikian model pembelajaran kooperatif ini memiliki "kelenturan medan" sehingga dapat digunakan pada berbagai tingkat kemampuan siswa.

\section{b. Penguasaan pengetahuan}

1) Dalam aspek pengetahuan sebagai dampak pengiring dari pembelajaran aspek keterampilan sosial, sekolahsekolah yang menjadi kelompok eksperimen, memperlihatkan perbedaan yang sangat berarti antara tes awal (peost test) dengan tes akhir (post test).

2) Perbedaan tersebut diperkuat oleh hasil uji perbedaan dengan kelompok control. Dalam setiap pasangan sekolah eksperimen dengan sekolah sosial diperoleh hasil bahwa skor rata-rata sekolah-sekolah dari kelompok eksperimen (yang menggunakan model pembelajaran komprehensif) hasilnya lebih tinggi dari skor rata-rata sekolah kelompok kontrol (yang menggunakan model pembelajarn biasa), dan perbedaannya sangat signifikan atau berarti.

3) Penguasaan hasil belajar pada aspek pengetahuan lebih homogen dibandingkan dengan dalam aspek keterampilan sosial.
4) Tingkat heterogenitas pencapaian aspek pengetahuan cenderung lebih menonjol pada kelompok eksperimen dibanding kelompok kontrol, hal itu menandakan bahwa penggunaan model pembelajaran kooperatif cenderung memberi keragaman hasil dalam aspek pengetahuan.

5) Model pembelajaran komprehensif lebih unggul dari pembelajaran biasa karena para siswa banyak melakukan variasi kegiatan dibandingkan dengan pembelajaran biasa. Melalui berbagai variasi kegiatan belajar tersebut mereka melakukan pengulangan, perluasan, pendalaman dan penguatan terhadap penguasaan materi pengetahuan yang dipelajari, sedang dalam pembelajaran biasa yang bersifat ekspositori, siswa hanya mengalami atau melakukan satu atau dua kegiatan belajar saja, sehingga tidak atau kurang terjadi pengulangan, perluasan, pendalaman dan penguatan penguasaan.

\section{Hambatan dan Optimalisasi Pelaksanaan}

Ada beberapa hambatan yang dihadapi dalam pelaksanaan model pembelajaran komprehensif.

1) Pertama, karena belum biasa guru tidak langsung dapat melaksanakan model pembelajaran komprehensif secara efektif, mereka membutuhkan penyesuaian atau latihan dalam pertemuan pertama, tetapi pada pertemuan berikutnya dapat lebih efektif.

2) Kedua, karena belum biasa para siswa juga membutuhkan waktu untuk menyesuaikan diri dengan kegiatan yang baru. Guru dituntut untuk lebih meningkatkan disiplin belajar terutama kebiasaan siswa berbicara dan bekerja lebih efisien. 
3) Ketiga, kegiatan-kegiatan kelompok yang mengaktifkan siswa membutuhkan waktu belajar yang relatif lebih lama. Masalah ini dapat diatasi dengan meningkatkan efisiensi penggunaan waktu, penentuan target sasaran dan waktu untuk setiap kegiatan, pengawasan dan perintah untuk segera mengakhiri sesuatu kegiatan dan berpindah ke kegiatan lainnya.

4) Keempat, adalah kelengkapan media dan sumber. Masalah ini merupakan masalah umum yang dihadapi oleh sekolah, dapat diatasi dengan meningkatkan kerjasama dengan unsur pimpinan dan komite sekolah, dan peningkatan upaya guru mengembangkan sendiri media dan sumber belajar.

7. Beberapa Prinsip Dasar yang Ditemukan

Berdasarkan berbagai pengamatan terhadap pembelajaran, mengkaji dan menyimpulkan temuan-temuan, ditemukan beberapa prinsip dasar atau dalil yang dapat dirumuskan berkenaan dengan model pembelajaran komprehensif.

a. Belajar dengan menggunakan model pembelajaran komprehensif dapat meningkatkan keterampilan sosial siswa.

b. Penguasaan materi pelajaran lebih meningkat dengan menggunakan pembelajaran komprehensif.

c. Pembelajaran yang menggunakan kegiatan kelompok yang bervariasi dapat meningkatkan motivasi belajar siswa.

d. Kegiatan berkelompok lebih efektif jika pengelompokkan dilakukan dengan kegiatan yang kreatif.

e. Penguasaan siswa dalam materi pelajaran meningkat melalui penggunaan kegiatan pembelajaran yang mengaktifkan siswa. f. Siswa lebih cepat menyesuaikan diri dengan kegiatan pembelajaran bila didahului dengan langkah orientasi.

g. Wawasan pengetahuan siswa lebih luas melalui penggunaan kegiatan komprehensif.

h. Penguasaan pengetahuan siswa lebih kuat melalui kegiatan pendalaman dan penguatan.

i. Penyimpulan diakhir pelajaran memperkuat pengusaan siswa dalam materi yang dipelajari.

\section{SIMPULAN}

Temuan-temuan dalam penelitian ini dapat menjadi masukan bagi berbagai pihak yang berperan dalam pengembangan konsep, pengelolaan, dan pelaksanaan pendidikan, khususnya pendidikan IPS, baik pada jenjang pendidikan dasar, pendidikan menengah, maupun pendidikan tinggi.

\section{Untuk guru}

Guru adalah pelaksana terdepan dari kurikulum dan pembelajaran. Guru-guru Sekolah Dasar dapat menggunakan hasil-hasil dari penelitian ini untuk meningkatkan proses dan hasil pembelajaran, khususnya dalam pembelajaran IPS. Hasil-hasil dari studi pendahuluan dapat dijadikan bahan perbandingan dengan kondisi yang ada di sekolahnya, kemudian dijadikan titik tolak peningkatan mutu pembelajaran.

Guru-guru kelas V dapat menggunakan model pembelajaran komprehensif yang dikembangkan dalam penelitian ini di kelasnya. Untuk topiktopik yang sama dengan topik yang dikembangkan dalam penelitian ini, rencana pembelajarannya dapat langsung digunakan, dengan terlebih dahulu membaca dan memahaminya secara cermat. Untuk topik-topik lain dalam pelajaran IPS di kelas V dapat langsung 
digunakan dengan didahului oleh beberapa penyesuaian sejalan dengan tema atau topik yang akan diajarkannya.

Model pembelajaran ini juga dapat digunakan di kelas IV dan kelas VI dengan beberapa penyempurnaan sesuai dengan karakteristik dan tingkat kemampuan siswa. Sebenarnya model pembelajaran ini juga dapat digunakan di kelas III, tetapi membutuhkan perhatian guru yang lebih intensif di dalam pelaksanaannya, sebab siswa kelas III kemampuannya masih terbatas, perhatiannya mudah goyah, keterampilan bekerja samanya masih perlu dikembangkan, sehingga membutuhkan pengendalian, pengawasan, dan bimbingan belajar yang lebih intensif.

Didahului dengan penyusunan rencana yang memadai dan sesuai dengan kontek serta potensi siswa, efektifitas penerapan model ini terkait erat dan sangat didukung oleh kemauan dan kemampuan guru untuk mengembangkan berbagai inovasi dan kreatifitas dalam pembelajaran. Bentuk kreatifitas atau inovasi guru dapat dikembangkan dengan mengembangkan berbagai variasi metode atau kegiatan, variasi pengelolaan sarana dan prasarana yang ada atau dihadirkan di kelas, variasi media, prasarana atau alat bantu belajar, pengkondisian tempat duduk, variasi pengelompokkan anak atau urutan pembelajaran itu sendiri. Semakin kaya improvisasi guru kegiatan pembelajaran semakin merangsang siswa untuk terlibat karena menarik dan tidak membosankan.

Pembiasaan penggunaan model pembelajaran komprehensif cukup meringankan tugas guru karena memfokuskan pembelajaran pada kegiatan siswa. Dalam kondisi demikian guru dapat mengoptimalkan berbagai kekuatan dan potensi siswa atau suasana di sekitar siswa.

\section{Untuk Kepala Sekolah}

Kepala sekolah adalah pengelola dan sekaligus juga pemimpin di sekolah. Inovasi dan upaya-upaya peningkatan mutu pendidikan yang dilakukan guru, harus diarahkan, didorong, dibantu dan difasilitasi oleh kepala sekolah. Untuk membantu memfasilitasi inovasi yang dilakukan guru, terlebih dahulu kepala sekolah harus menguasai model atau acuan tersebut.

Bentuk fasilitas utama dari kepala sekolah yang dibutuhkan dalam implementasi model pembelajaran kooperatif berkenaan dengan dukungan saat mengimplementasikan kurikulum sehingga guru merasa leluasa dalam mengembangkan berbagai inovasi dan kreatifitas mengajar. Keterikatan sasaran hasil sebagaimana menjadi kendala saat ini harus difahami secara proporsional sehingga target guru mengajar tidak terbebani hanya pada satu sasaran.

Dukungan kedua berkenaan dengan ketersediaan, kecukupan serta keberfungsian berbagai sarana, prasarana serta sumber belajar karena efektifitas pembelajaran komprehensif didukung oleh komponen tersebut. Semakin lengkap semakin memudahkan guru dalam membangun pembelajaran karena terbukti dengan contoh dan alat bantu realita kemampuan kerjasama dan hasil belajar siswa relatif lebih efektif.

Model pembelajaran komprehensif dapat dijadikan salah satu contoh model dan juga acuan oleh kepala sekolah dalam mendorong, membina dan memfasilitasi inovasi dan peningkatan mutu proses dan hasil pembelajaran di sekolahnya. Dengan acuan model pembelajaran komprehensif yang dihasilkan dalam penelitian ini, Kepala Sekolah dapat mendorong penggunaannya 
pada topik lain di kelas $\mathrm{V}$, pada tingkatan kelas lain di sekolahnya atau menginformasikan keunggulannya kepada pada kepala sekolah lain baik untuk pembelajaran IPS maupun mata pelajaran lain yang berkarakteristik materi cocok dengan model ini.

\section{Untuk Dinas Pendidikan}

Kepala sekolah hanya bertugas dan bertanggung jawab terhadap inovasi yang diadakan di sekolahnya. Untuk inovasi dan peningkatan mutu pendidikan pada sekolah yang lebih luas menjadi tugas dan tanggung jawab Dinas Pendidikan, tingkat kecamatan, kota atau kabupaten dan tingkat propinsi.

Disamping sosial dukungan langsung untuk membantu mempermudah dalam memfasilitasi berbagai kebutuhan belajar siswa, Dinas Pendidikan juga dapat mensosialisaikan model pembelajaran kooperatif yang dikembangkan dalam penelitian ini sebagai model dan acuan dalam pelaksanaan inovasi dan peningkatan mutu pendidikan pada tingkat kecamatan, kota/kabupaten dan propinsi, khususnya dalam pembelajaran IPS di kelas V. Model ini juga dapat digunakan pada kelas III, IV dan kelas VI dengan beberapa penyesuaian.

\section{Untuk Peneliti Selanjutnya}

Penelitian ini berkenaan dengan pembelajaran IPS di kelas V dengan fokus pengembangan keterampilan sosial. Hasil penelitian menemukan bahwa model pembelajaran yang cocok dan cukup efektif untuk mengembangkan keterampilasosial di kelas $\mathrm{V}$ adalah pembelajaran kooperatif. Penelitian ini cukup terbatas, hanya mengembangkan model pembelajaran bagi pengembangan keterampilan sosial di kelas V. Masih terbuka kesempatan bagi para peneliti lain untuk meneliti hal lainnya, seperti model: pembelajaran kooperatif pada kelas-kelas lainnya di sekolah dasar, sekolah lanjutan pertama dan lanjutan atas, pembelajaran koopertif pada mata-mata pelajaran lainnya, model pembelajaran lain untuk mengembangkan keterampilan sosial.

Keberhasilan implementasi model ini juga memerlukan berbagai dukungan, bukan hanya kemauan dan kemampuan peneliti untuk menggali dengan tepat berbagai potensi bacaan dan hasil penelitian sebelumnya, juga kemampuan melakukan atau mengembangkan inovasi dan kreatifitas untuk model pembelajaran, kecukupan waktu dan kemampuan untuk melakukan pendekatan, kerjasama serta pelatihan bagi para guru sebelum mengimplementasikan model di sekolah yang dijadikan objek penelitian. Dengan ketepatan pendekatan tersebut maka beberapa hambatan yang terjadi bisa teratasi.

\section{DAFTAR PUSTAKA}

Boediono, et.al.,(1999), Penyempurnaan Kurikulum 1994 Berbasis Kemampuan Dasar. "Jurnal Pendidikan dan Kebudayaan, 5 (018), 82-97.

Depdikbud (1999). Hasil Evaluasi Kurikulum 1994 untuk SD. Jakarta. Pusat Pengembangan Kurikulum dan Sarana Pendidikan Balitbang Depdikbud

Human Development Report 2013: Work for Human Development

https://fatirul.files.wordpress.com/.../ pengembangan-pembelajarancooperat...27 Nov 2008 - Naisbitt (dalam Fong 1999) 
Sumaatmadja, Nursid., (1986), Pengantar

Ilmu Sosial (IPS), Bandung:Alumni.

Sumantri, HM. Nu'man, (2001), Menggagas Pembaharuan Pendidikan

Ilmu Pengatahuan Sosial, Bandung UPI: Rosdakarya.

Peraturan Menteri Pendidikan Nasional Republik Indonesia Nomor 23 Tahun 2006 Tentang Standar Kompetensi Lulusan Untuk Satuan Pendidikan Dasar Dan Menengah 